\title{
Sustainability through Innovations of Enterprise Architecture (EA) in Public Sector's Management: Issues \& Challenges
}

\section{Surya Sumarni Hussein, Mohd Naz'ri Mahrin and Nurazean Maarop}

Advanced Informatics School, Universiti Teknologi Malaysia (UTM), Kuala Lumpur, Malaysia

Correspondence should be addressed to: Surya Sumarni Hussein; cuyasuryahussein@gmail.com

Received date: 31 March 2016; Accepted date: 3 May 2017; Published date: 4 July 2017

Academic Editor: Amal Hayati Ishak

Copyright (C) 2017. Surya Sumarni Hussein, Mohd Naz'ri Mahrin and Nurazean Maarop. Distributed under Creative Commons CC-BY 4.0

\begin{abstract}
Innovations through Enterprise Architecture (EA) require a transformation in public sector's management. EA has been identified as one of the prime initiatives towards public sector transformation. EA implementation is highly recommended to execute efficient and effective public service delivery. However, building upon several public sector agencies that had implemented these initiatives, EA implementation in Malaysian Public Sector (MPS) was reported as unfavourable. This study aims to identify related issues and challenges towards sustainability of EA implementation. A qualitative research approach was employed in this study. Semi structured interview was held involving five EA experts. From the analysis, six related issues such as (i) absence of the mandate from government to implement EA initiatives; (ii) improper EA governance leading to difficulty in managing EA implementation; (iii) absence of EA tool to maintain EA document; (iv) lack of EA awareness (v) lack of EA readiness and (vi) limited knowledge and skills on EA among the team were discerned in sustaining EA practices. With regard to the practical implication, this paper can serve as reference in EA implementation in the public sector.
\end{abstract}

Keywords: Enterprise Architecture, EA Management, innovation, public sector, sustainability, issues and challenges

\section{Introduction}

Enterprise Architecture (EA) is concerned with the systematic arrangement of different business processes, procedures, standards, rules and regulations, information systems and technical infrastructure of current information and expected future transformations and goals (Janssen, 2012; Maheshwari, Janssen, \& van

Cite this Article as: Surya Sumarni Hussein, Mohd Naz'ri Mahrin and Nurazean Maarop (2017), " Sustainability through Innovations Of Enterprise Architecture (EA) in Public Sector's Management: Iscues \&, Challenoes" Inurnal of Coutheact Acian Recearrh Vol On17 (On17) Article In 73)กว7 
Veenstra, 2011; Van Der Raadt et al., 2010). EA function basically defined as organizational functions as a whole that interrelate through formal (governance) and informal (collaboration) processes at enterprise, domain, project, and operational levels (Van Der Raadt et al. 2010). Therefore, in a wider perspective, EA is a holistic approach that is not only limited to IT but also aligns with the business.

Public sectors were increasingly aware of the importance of employing Egovernment to improve the delivery of public services to the people (Sebastian \& Supriya, 2013). This becomes the main agenda towards transformation of public sector service delivery. According to Malaysian Public Sector (MPS) ICT Strategic Plan 2011-2015, ICT transformation agenda planned to support four ICT Strategic Thrust that are (i) enhancing service delivery (ii) connected government (iii) good governance and (iv) sustainable and resilient ICT. In order to transform, this four strategic thrust that consists of business and IT driven needs to be aligned. This can be achieved by embarking EA practices. According to Waseda University World E-Government Ranking Government, EA is relevant with the transformational government goals to ensure efficient government management by improvement of interactions with business, citizens and within the government agencies (Obi \& Iwasaki, 2010). Consequently, interest in EA in the public sector is increased in receiving attention (Dang \& Pekkola, 2016).

A study by Roeleven \& Broere (2009) reveals that more than 66 percent of EA program in Netherlands did not fulfil expectation due to longer time spent during EA establishment process itself. A number of studies have focused on EA development issues and challenges (Isomäki \& Liimatainen, 2008; Jahani, Javadein, \& Jafari, 2010; Kaisler, Armour, \& Valivullah, 2005; Seppanen, Heikkila, \& Liimatainen, 2009; Ylimäki, 2006).

Most developed nations have embarked on this phenomenon in recent years because without EA an organisation will risk being uncompetitive, ineffective, inefficient, and lack resilience to challenges from and within the environment. Thus, EA brings innovation in managing MPS (MAMPU 2015; Nikpay et al. 2015). However, organisation has become complex over the year due to the rapid development of technology and the vast number and complexity of information systems in the running operations (Seppanen et al., 2009). This includes the public sector towards more responsive service to the citizens and businesses. Managing the interrelationships and growing demands on business agility, EA acts as an innovation mechanism to overcome this complexity by aligning between business and IT (Iyamu \& Mphahlele 2014; Seppanen et al. 2009; Aier \& Schelp 2010). Prior to this, EA is a structured approach used to manage and define an organisation across different domains. It is often used as a practice to help transform the organisation through understanding, reconciling and planning across the Business, Data, Application and Technology domains (MAMPU 2015; Nikpay et al. 2015). According to the result of the research being conducted among $\mathrm{CIO}$ in the public sector, Whole of Government (WoG) approach is through EA (MAMPU, 2016). EA act as an ecosystem enabler (MAMPU, 2016). This ecosystem enabler is needed to support the implementation of IT Strategic Thrust.

To date, EA is implemented in five public sector agencies in Malaysia. Malaysian Public Sector has come out with an initiative called 1 Government Enterprise Architecture or 1GovEA. 1GovEA act as a blueprint to improve consistent and comprehensive Digital Government service delivery. However, based on the EA maturity assessment conducted by Malaysian Administrative Modernisation and Management Planning Unit (MAMPU) in 2014, the study reveals that in general the MPS is moving towards Level 2 (Formalised Stage) with regards to the adoption of EA practices (MAMPU, 2014). Based on the findings of the study, issues and challenges are identified towards sustainability of EA practices (MAMPU 
2015). Thus, EA approaches receive major criticisms due to issues related to frequent changes in processes, landscape, practices and procedures of government and governance (Van Der Raadt et al. 2010; Maheshwari et al. 2011; Janssen 2012). There is lack of readiness to establish and manage EA practices in organisation that lead to sustainability of EA in a long run.

This paper aims to identify and categorise the issues and challenge of EA management in public sector since less attention is given in this area in the existing academic publications. In this study, first, the literature was studied to find out the EA definition criteria and followed by conducting interview with experts in MPS that have implemented EA. The following sections in this paper are organized as follows; Section 2 describes the literature review, which focuses on EA and the public sector EA. Section 3 describes the research methodology used for this study. Section 4 reports the result and analysis of the findings. Finally, Section 5 concludes and provides recommendations for further research on this research area.

\section{Literature Review}

This section explains the reviews of current literatures which consist of three subsections; EA, innovation of EA towards transformation and public sector EA.

\section{Enterprise Architecture (EA)}

EA is an approach for an organisation to plan strategically to facilitate decision making process through systematic arrangement. It also can act as a blueprint for organisations to achieve current and future business objectives by alignment of strategy with business and technology. EA is concerned with a systematic arrangement of different business processes, procedures, standards, rules and regulations, information systems and technical infrastructure of current information and expected future transformations and goals (Janssen, 2012; Maheshwari et al., 2011; Van Der Raadt et al., 2010). EA function is defined as organizational functions as a whole that interrelate through formal (governance) and informal (collaboration) processes in the enterprise, domain, project, and operational levels (Van Der Raadt et al., 2010). Therefore, in a wider perspective, EA is a holistic approach that is not only limited to IT but also aligned with the business.

\section{Innovation of EA towards Transformation}

The increasing attention for EA in government is also due to the transformational government initiatives (Bakar, Kama, \& Harihodin, 2016; Ross, Weill, \& Robertson, 2006; Simon, Fischbach, \& Schoder, 2014). However, Curran et al. (2016) stated that any transformation efforts need to be driven by business process. A technology-first approach that doesn't align to business transformation efforts will fail to deliver the anticipated return and will quickly become irrelevant. EA transformation, i.e. a clearly defined step in taking EA from an existing/initial state (often referred to as baseline state) to a desired state (often referred to as target state), in line with the EA strategy, is enabled by the EA strategy, roadmap and governance (Saha, 2009). EA acts as an enabling ecosystem for transformation towards digital government (Ibrahim, 2016).

The elements for a successful transformation are organisation, people, process and technology (Ramakrishnan \& Testani, 2011). Saha (2009) stated that beginning EA with this simple recognition and ensuring that people are at the centre of the architecture - the big picture of change - is a strong first step towards successful transformation. Thus, these elements need to be considered to innovate the way for an organisation to transform.

\section{Public Sector EA}

Increasingly, EA in public sector efforts is part of Electronic Government (EGOV) programs conducted by national and other levels of governments. A major application area for the Public Sector EA practice, Electronic Government (EGOV) is defined 
as the strategic use of Information and Communication Technology (ICT) by governments to enable transformation in service delivery, relationships with key stakeholders, and internal working and management in government (Ojo et al., 2011).

One reason for the increasing prominence of Public Sector EA as a management and technology practice in government is its association with the transformational government goals (Ojo et al., 2011). Public Sector EA can be viewed as a practice or an artefact. As a practice, it enables rigorous description, design and analysis of organizational structures that span the boundaries of different organizations. As an artefact, it comprises principles, methods and models used to design and implement organizational structures, business processes, and information systems and infrastructure of an enterprise (Ojo et al., 2011). According to Jahani et al. (2010), architectures can cover a range from general architecture for the whole government to very specific for a certain organization in one particular domain. The unique differences in the governmental environment compared to corporate enterprises have also stirred a discussion of what could and should be the best practice of using EA in the public (Klischewski, 2014).

The MPS EA initiative was initiated from the Transformation Program (TP) and the first EA blueprint was developed from October 2013 until February 2014. The EA blueprint was developed based on the framework defined by an external consulting firm as a guide to build IT environment that supports the business needs. The agency's main objective of EA is to facilitate collaboration on the standardization of data, application and infrastructure. The final aim is to ensure relevant data can be shared across multiple business functions through common applications and infrastructure (Bakar, Kama, et al., 2016).

\section{Research Methodology}

The research seeks to further understand the EA implementation challenges to sustain EA initiatives using semi structured interview from experts' perspective in MPS settings. Semi structured interview is an approach in qualitative methods with strength in obtaining a deep understanding of a phenomenon from the people (Creswell, 2012). The necessity exploration is to expand the understanding of the issues and challenges in the real settings. As a whole, appropriate research methodology creates platform to have a proper activity in relevance area and it guides the researchers in the right direction. This research framework focuses on issues and challenges of EA implementation. This study's aim is to collect current issues on EA implementation based on a defined research framework especially in the current decade. According to Kumar (2011), the main focus of qualitative study is to understand, explain, explore, discover and clarify situations, feelings, perceptions, attitudes, values, beliefs and experiences of a group of people. Hence, this study is using a qualitative approach to identify related issues and challenges towards sustainability of EA implementation. Figure 1 shows the process in conducting this study. 


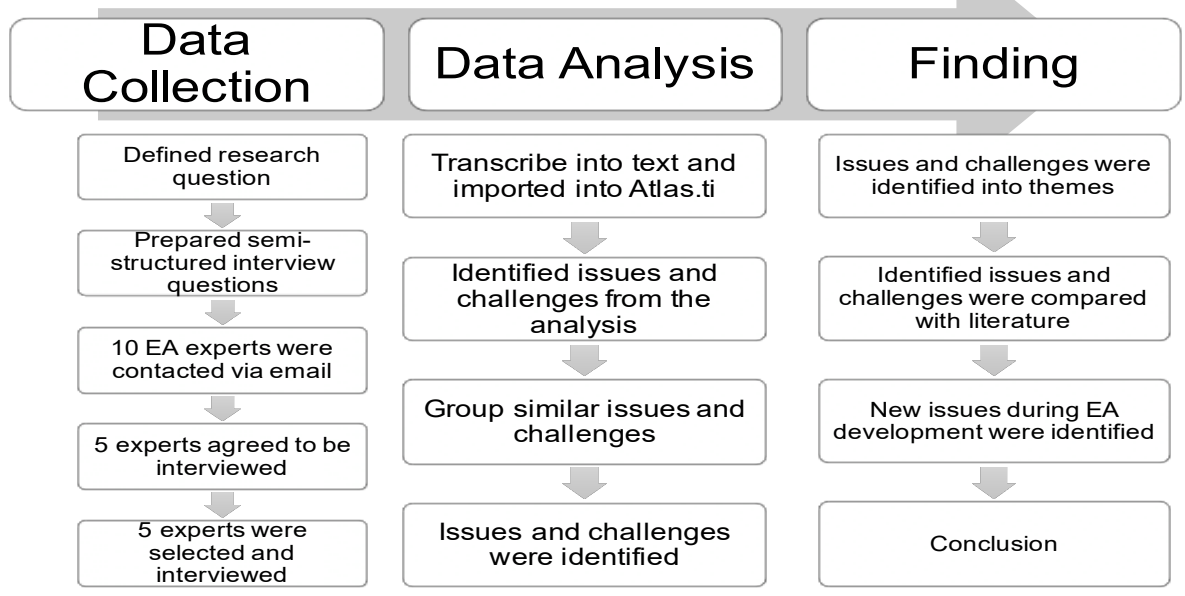

Figure 1: Overview of research approach

\section{Data collection}

Before data collection was conducted, the research question needed to be defined. The main question of this study was "What are the related issues and challenges towards sustainability of EA implementation in managing public sector organisations?" To answer this research question, qualitative methods were used. Following qualitative methods, data were collected using semi-structured interviews. Before the interview, there was a session to introduce the objectives of the interview and to briefly explain the interview objectives and settings. In the data collection, a series of interviews were conducted with five experts from public and private sectors agencies in Malaysia to understand the issues and challenges in EA implementation in MPS. The initial interview was conducted in an environment that involves the public sector and industry respondents, that is EA experts in Public Sector and Private Sector. Data were interpreted based on respondent's experience and examples of cases discussed during the interview sessions. Interviews were conducted separately from 24 March to 18 May 2016. Experts' criteria and information related are shown in Table 1. 
Table 1: Experts' Selection and Criteria

\begin{tabular}{|l|l|l|l|l|l|}
\hline Position & $\begin{array}{l}\text { Chief ICT } \\
\text { Consultant } \\
\text { (Strategic) }\end{array}$ & $\begin{array}{l}\text { ICT Expert } \\
\text { (Information } \\
\text { Management } \\
\text { and EA in } \\
\text { MPS) }\end{array}$ & $\begin{array}{l}\text { Principal } \\
\text { Assistant } \\
\text { Director (EA } \\
\text { Practitioner } \\
\text { \& TOGAF 9.1 } \\
\text { Certified) }\end{array}$ & $\begin{array}{l}\text { ICT Expert } \\
\text { (Information } \\
\text { Management } \\
\text { and EA in } \\
\text { MPS) }\end{array}$ & $\begin{array}{l}\text { lhief Architect } \\
\text { of EA Office } \\
\text { (EA } \\
\text { Practitioner \& } \\
\text { TOGAF 9.1 } \\
\text { Certified) }\end{array}$ \\
\hline Expert Id & Expert 1 & Expert 3 & Expert 4 & Expert 5 & Expert 2 \\
\hline Agency & Agency A & Agency A & Agency A & Agency B & Company A \\
\hline Category & $\begin{array}{l}\text { Top } \\
\text { Managemen }\end{array}$ & $\begin{array}{l}\text { Middle } \\
\text { Management }\end{array}$ & Operation & Operation & $\begin{array}{l}\text { Top } \\
\text { Management }\end{array}$ \\
\hline $\begin{array}{l}\text { Experience } \\
\text { in EA } \\
\text { practices }\end{array}$ & 6 years & 5 years & 5 years & 5 years & 10 years \\
\hline $\begin{array}{l}\text { Experience } \\
\text { in ICT } \\
\text { projects }\end{array}$ & 35 years & 20 years & 10 years & 15 years & 20 years \\
\hline $\begin{array}{l}\text { Interview's } \\
\text { Information }\end{array}$ & $\begin{array}{l}24 \text { Mac } \\
\text { (Thursday) }\end{array}$ & 9 May 2016 \\
(Monday) & $\begin{array}{l}18 \text { May 2016 } \\
\text { (Tuesday) }\end{array}$ & $\begin{array}{l}10 \text { May 2016 } \\
\text { (Tuesday) }\end{array}$ & $\begin{array}{l}\text { 5 May 2016 } \\
\text { (Thursday) }\end{array}$ \\
\hline
\end{tabular}

\section{Data Analysis}

The data collection shall ensure to capture the data related to the EA implementation issues and challenges. In order to do that, the researcher analysed the data from the audio recording during the interview - that must be transcribed for each of the interviews (Yin, 2013). Furthermore, the analysis will be conducted based on thematic analysis (Clarke \& Braun, 2013). The thematic analysis process based on open coding will be carried out as usual, but analysis codes for a theme have been assigned based on the unit of data analysis. According to Yin (2010), the unit of analysis selection is critical to understand how the evaluation might relate to any broader body of knowledge. The unit of analysis for this validation is then concentrated on the issues and challenges during EA implementation in MPS. In this research, the data coding process is done by using Atlas.ti ${ }^{\mathrm{T}}$, the Computer Assisted/Aided Qualitative Data Analysis (CAQDAS) software. In the coding phase, the transcripts were read repeatedly to highlight parts of the text and to emphasize the sections and issues that seemed to be important and relevant.

\section{Findings and Discussions}

This section represents collected information about issues and challenges of EA implementation based on defined research method.

\section{Absence of the mandate from government to implement EA initiatives}

Organisation needs direction to sustain. This direction usually comes from clear vision and mandate from stakeholder. According to Bakar (2013), it is important 
to have a mandate on MPS EA rules and processes to ensure this initiative will be implemented by all agencies. However, there is absence of mandate from government to implement EA initiatives. This issue is highlighted by expert 5 from agency B:

"Yes, we are interested to implement EA in our agencies and believe it is a good initiative to be implemented in our organisation. However, it is difficult to get buy in from the stakeholder because of the mandate. Compared to ICT Strategic Planning (ISP) initiatives, it already become a compulsory for agencies to have ISP to comply for a star rating criteria. So, it is important to have a mandate to ensure the MPS EA benefits are recognised throughout the governmental sector."

Prior studies have highlighted how public sector EA cognition (Kamogawa \& Okada, 2008) and political influence Gravesen (2012) may affect the success of public sector EA initiative. Gravesen (2012) holds the view that any public sector EA agendas should be anchored at the highest level of government, not in IT or in offices of the Chief Information Officer (CIO) only.

\section{Improper EA governance leads to difficulty in managing EA implementation}

One of the main problems an enterprise has to face today is sustainability in a dynamic environment (Schoenherr \& Aier, 2005). The interviews revealed that the public sector organisations had issues and challenges to sustain EA implementation in its organisations. Public sector agencies, more often than any other, have cleared and defined structure. In MPS, defined scopes and roles of individuals are not only the standard, but are typically recorded with detailed job descriptions and organizational charts. The structure is in vertical and imposed bureaucracy. However, this structure depends on size of organization and agency's type. In the words of an EA Expert 1 from Agency A:
"In our agencies, the organization depends on the size of workers. For public agencies, there a federal agency, state agencies and statutory bodies that have different organization set up and structure. To come out with a standard governance structure for EA team is quite a challenge based on this variation of organization set up. Therefore, standard governance of EA is a must in an organization to ensure sustainability of EA implementation."

In addition, Expert 1 from Agency A suggested that a good governance depends on strategy on mobilization of resources together with management of change will lead to success of EA practices.

\section{Absence of EA tool to maintain EA document}

Reliable and user friendly EA tools influenced the MPS EA establishment process. Therefore, the selection of suitable tools is made with a thorough discussion involving all MPS EA Team. According to expert 4 from agency $A$ :

"Tools is important to help us in managing and updating diagrams, artefact and documentation regarding EA. However, MPS need to consider having tools that is easy to use and reliable as well as secured to ensure smooth operation in embracing EA journey. As EA will become one of the medium to integrate all the government initiatives, we need a central repository to allow us to store and information. Yes, it will be good if we can have suitable EA tools to support our personnel, the EA team during EA implementation."

Gravesen (2012) claims that platforms that are open, standardised and adaptive, allow public sector EA development team to get involved in a flexible manner but yet still meeting the same public sector EA deliverables. Public sector EA programs should be employed incrementally and offer architecture frameworks that allow certain flexibility to participating organisation. 


\section{Lack of EA awareness}

Success of EA implementation depends on awareness factor. Roeleven \& Broere (2009) stated that limited awareness of the EA implementation within the organization, and organizational politics were the major contributing factors to a lack of success. Bossert \& Laartz (2016) support this by research that indicates a general lack of awareness of enterprisearchitecture groups within most organizations-who they are and what they do. Awareness programs, such as training and certification need to be conducted throughout the organisation (Bakar, Harihodin, \& Kama, 2016). Architectural awareness and involvement throughout the organization need to be spread (van Steenbergen, van den Berg, \& Brinkkemper, 2007). As mentioned by expert 5 from agency B:

"We need to create awareness and understanding of EA. Issues usually occur in establishing and maintaining continues awareness on EA to business users. We need to raise awareness on EA among public sector agencies thorough the various sessions held in this project. Nobody in our team had experience in EA. All of us have a background in IT. We do not understand what EA is, whether a human resource, financial issue, what the policies are, and so on. We are spending a lot of time discussing the topic."

Expert 3 from agency A stated:

"Some agencies sent their staff to courses to gain basic knowledge and obtain certificates, such as TOGAF and Zachman. Other agencies used consultants and outside experts to help their EA teams. Unfortunately, that combination was usually unsuccessful due to the dissimilar views and the lack of general awareness of EA and its expected benefits. This made it difficult to find consensus among the consultants, experts, and civil servants on even the simplest details, which caused severe delays and wasted time. When we proposed EA requirements, we strongly depended on the consultants, who actually don't have any understanding of our culture, environment, and business services."

\section{Lack of EA readiness}

Indeed, in practice, this entails firstly a need to predict the readiness of agencies to participate in EA work and to be able to participate in cross-public sector services (Liimatainen, Hoffmann, \& Jukka, 2007). The early experience shows that the process of establishing a public sector EA is a tedious and complicated process (Seppanen et al., 2009). Therefore, dealing with readiness is a major concern in EA. Lack in assessment of EA readiness negatively affects the establishment of EA in the MPS agency. However, there is no standard assessment to measure readiness in MPS. Current EA readiness assessment model is based on industries consultant and readiness assessment instrument that are not based on validated research. According to expert 3 from agency B:

"EA implementation is not just a project, it is a continues practice. However, most of the agency understand that EA is a one-time project which one's executed it is already a success. Thus, it is important for the agencies to be ready to implement EA in their organisation in a long run. Assessment that suit our environment is a must because we need to tackle the factors that enable us to move forward and sustain in this journey. Currently, lack of assessment being made to assess organisation readiness towards EA implementation. It is based on project initiate with appointed private consultant. Therefore, I like to suggest that we can have our own standard readiness assessment mechanism that suite our environment and can be used periodically."

Expert 1 from agency B also added that if the agencies know which point of readiness they need to tackle, it is easier for them to focus on what needs to be done first to ensure smooth sailing. This statement is also supported by expert 2 from company A that suggested EA readiness assessment 
is important to identify any risk before embarking on this journey.

\section{Limited knowledge and skills on EA among the team}

The personnel in the agencies in IT department focused on the IT and technical perspective. They also had experience with IT projects but not with EA. Under the circumstances, the EA programs ignored business services and emphasized IT issues. Agencies need to have EA teams that have abilities and skills on running EA activities. EA expertise, experiences, background, and views on how EA should work and what its role are crucial criteria that need to look into. Under the circumstances, the EA programs ignored business services and emphasized IT issues. An EA expert 5 from agency B stated:

"Our personnel had no experience in EA. All of us have a background in IT. Most of them do not understand what EA is, whether is another strategic initiative related to business or another policy being enforce in an organization. We do send some of the personnel to EA courses to address these issues and run some of awareness program such as technology update to enhance the knowledge on EA."

Some agencies sent their personnel to courses to gain basic knowledge and obtain certificates, such as TOGAF and Zachman. Other agencies used consultants and outside experts to help their EA teams. Unfortunately, that combination was usually unsuccessful due to the dissimilar views and the lack of general awareness of EA and its expected benefits. This made it difficult to find consensus among the consultants, experts, and personnel on even the simplest details, which caused severe delays and wasted time. An expert 2 from company A stated:

"Some of the agency need to rely on industry consultants to establish EA in their agencies to expedite the process of establishment but they also have to really involved with us so that we can understand of their culture, environment, and business services better and they can learn faster from us. Yes, there are also agencies that established their EA in-house but the process take longer time because lack off skill and knowledge on EA.

Based on the input, readiness becomes the main concern in the implementation of EA. Table 2 depicted the analysed results of the experts' interviews on issues and challenges to sustain EA implementation in their organizations. All the experts highlighted that readiness is the main issue regarding sustainability of EA implementation in MPS. Preparation of people, process, environment of organisation and technology is important to adapt new initiatives (Salleh, Alshawi, Mohamed Sabli, Zolkafli, \& Judi, 2011; Simon et al., 2014). Other than that, four of the experts highlighted that it is important to have standard governance for EA team to ensure smooth management of EA. Less issues on EA tools due tools are seen as facilitating EA management. According to Rouhani, Mahrin, Nikpay, Ahmad, \& Nikfard (2015), at lower levels of maturity, the focus should be on people. It does not expect the EA tools to do the job. Thus, MPS EA maturity is at the low level and tools is not the main issues (MAMPU, 2014) The main concern is more towards readiness of the organisation itself. 
Table 2: Analysed result of the interviews

\begin{tabular}{|c|c|c|c|c|c|c|}
\hline \multirow[b]{2}{*}{$\begin{array}{l}\text { Issues and } \\
\text { Challenges } \\
\text { (Themes) }\end{array}$} & \multirow[b]{2}{*}{ Descriptions } & \multicolumn{5}{|c|}{ Experts' input } \\
\hline & & $\begin{array}{c}\text { Expert } \\
1\end{array}$ & $\begin{array}{c}\text { Expert } \\
2\end{array}$ & $\begin{array}{c}\text { Expert } \\
3\end{array}$ & $\begin{array}{c}\text { Expert } \\
4\end{array}$ & $\begin{array}{c}\text { Expert } \\
5\end{array}$ \\
\hline $\begin{array}{l}\text { No mandate from } \\
\text { government to } \\
\text { implement EA } \\
\text { initiatives }\end{array}$ & $\begin{array}{l}\text { Refers to no policy or } \\
\text { circular towards EA } \\
\text { implementation being } \\
\text { enforced to } \\
\text { organisation }\end{array}$ & $\sqrt{ }$ & - & $\sqrt{ }$ & - & $\sqrt{ }$ \\
\hline $\begin{array}{l}\text { Improper EA } \\
\text { governance leads } \\
\text { to difficulty in } \\
\text { managing EA } \\
\text { implementation }\end{array}$ & $\begin{array}{l}\text { Refers to different } \\
\text { governance structures } \\
\text { set up based on the size } \\
\text { of the organisation and } \\
\text { create variety in EA } \\
\text { governance structure }\end{array}$ & $\sqrt{ }$ & - & $\sqrt{ }$ & $\sqrt{ }$ & $\sqrt{ }$ \\
\hline $\begin{array}{l}\text { Absence of EA tool } \\
\text { to maintain EA } \\
\text { document }\end{array}$ & $\begin{array}{l}\text { Refers to tool such as } \\
\text { EA repository tool and } \\
\text { EA modelling tool }\end{array}$ & $\sqrt{ }$ & $\sqrt{ }$ & - & - & - \\
\hline $\begin{array}{l}\text { Lack of EA } \\
\text { awareness }\end{array}$ & $\begin{array}{l}\text { Refers to lack of } \\
\text { understanding of EA } \\
\text { initiative }\end{array}$ & - & $\sqrt{ }$ & $\sqrt{ }$ & - & $\sqrt{ }$ \\
\hline $\begin{array}{l}\text { Lack of EA } \\
\text { readiness }\end{array}$ & $\begin{array}{l}\text { Refers to lack of } \\
\text { readiness in EA } \\
\text { implementation }\end{array}$ & $\sqrt{ }$ & $\sqrt{ }$ & $\sqrt{ }$ & $\sqrt{ }$ & $\sqrt{ }$ \\
\hline $\begin{array}{l}\text { Limited } \\
\text { knowledge and } \\
\text { skills on EA among } \\
\text { the team }\end{array}$ & $\begin{array}{l}\text { Refers to knowledge } \\
\text { and skills required for } \\
\text { the team to manage EA } \\
\text { initiatives }\end{array}$ & - & $\sqrt{ }$ & $\sqrt{ }$ & $\sqrt{ }$ & - \\
\hline
\end{tabular}

\section{Conclusions}

The aim of this study is to identify related issues and challenges towards sustainability of EA implementation. To conclude, this study identifies six issues and challenges from the interview of five experts from MPS organisations that already implement EA. Through this investigation, EA issues and challenges that have been described by experts in real organizations demonstrated similarity to the set of challenges from the literature. There are two most highlighted issues in EA implementation that include lack of governance and lack of readiness as the cause that impacts the EA sustainability. Therefore, it is important to tackle these issues.
Prior to this, for EA to act as a transformation mechanism towards

innovation in public sector management, an organisation needs to consider the issues and challenges identified. This study has no claim to be complete. Further research is required to extend the findings. However, at this present stage, this paper can serve MPS and other practitioners as a reference in considering issues and challenges before implementing EA in their organisation. From an academic perspective, this paper represents a theory for identifying issues and challenges towards sustaining EA practices in public sector organisations. 


\section{Acknowledgement}

The study is financially supported by Research University Grant Tier 1 Q.130000.2538.11H82, University Teknologi Malaysia, Public Service Department of Malaysia and Ministry of Education Malaysia.

\section{References}

1. Aier, S., \& Schelp, J. (2010). A Reassessment of Enterprise Architecture Implementation. Service-Oriented Computing. ICSOC/ServiceWave 2009 Workshops, $\quad 6275, \quad 35-47$. http://doi.org/10.1007/978-3-642-161322_4

2. Bakar, N. A. A. (2013). Influence Factors in Government Enterprise Architecture Establishment Process: A Preliminary Findings, (June), 1-6.

3. Bakar, N. A. A., Harihodin, S., \& Kama, N. (2016). Assessment of Enterprise Architecture Implementation Capability and Priority in Public Sector Agency. Procedia Computer Science, 100, 198-206. http://doi.org/10.1016/j.procs.2016.09.14

4. Bakar, N. A. A., Kama, N., \& Harihodin, S. (2016). Enterprise architecture development and implementation in public sector: The Malaysian perspective. Journal of Theoretical and Applied Information Technology, 88(1), 176-188.

5. Bossert, O., \& Laartz, J. (2016, February). How enterprise architects can help ensure success with digital transformations. McKinsey \& Company, 1$6 . \quad$ Retrieved from http://www.mckinsey.com/businessfunctions/digital-mckinsey/ourinsights/how-enterprise-architects-canhelp-ensure-success-with-digitaltransformations

6. Clarke, V., \& Braun, V. (2013). Teaching thematic analysis : Overcoming challenges and developing strategies for effective learning Associate Professor in Sexuality Studies Department of Psychology Faculty of Health and Life Sciences University of the West of England Coldharbour Lane $\mathrm{Br}$, 26(2013), 120-123.

7. Creswell, J. W. (2012). Educational research: Planning, conducting, and evaluating quantitative and qualitative research. Educational Research (Vol. 3).

8. Curran, C., Drisko, C., \& Topdjian, J. (2016, February). Reinventing Enterprise Architecture in a digital world Looking at EA through a capabilities lens. PWC. Retrieved from https://www.pwc.com/us/en/increasingit-effectiveness/publications/technologypublications/assets/reinventingenterprise-architecture-digital-world.pdf

9. Dang, D. D., \& Pekkola, S. (2016). Root Causes of Enterprise Architecture Problems. Pacific Asia Conference on Information Systems (PACIS). Retrieved from http://aisel.aisnet.org/pacis2016

10.Gravesen, J. K. (2012). What defines success with public sector enterprise architecture, 1-14.

11.Ibrahim, N. (2016). ENTERPRISE ARCHITECTURE IMPLEMENTATION IN THE MALAYSIAN PUBLIC SECTOR: Empowering Enterprise Architect To Lift Digital Business Strategy. Retrieved fromhttp://cioconvex.mampu.gov.my/dow nload/3_Norhamimah(MAMPU)_EA_in_Mal aysian_Public_SectorCIO_Convex_2016_v4. 1.pdf,

12.Isomäki, H., \& Liimatainen, K. (2008). Challenges of Government Enterprise Architecture Work-Stakeholders' Views. Electronic Government 7th International Conference EGOV 2008 Turin Italy, 35, 364-374. Retrieved from http://www.springerlink.com/index/X205 281N10821V7H.pdf

13.Iyamu, T., \& Mphahlele, L. (2014). The impact of organisational structure on enterprise architecture deployment. Journal of Systems and Information Technology, 16(1), 2-19. http://doi.org/10.1108/JSIT-04-20130010 
14.Jahani, B., Javadein, S. R. S., \& Jafari, H. A. (2010). Measurement of enterprise architecture readiness within organizations. Business Strategy Series, 11(3), 177-191. http://doi.org/10.1108/17515631011043 840

15.Janssen, M. (2012). Sociopolitical Aspects of Interoperability and Enterprise Architecture in E-Government. Social Science Computer Review, 30(1), 24-36. http://doi.org/10.1177/08944393103921 87

16.Kaisler, S. H., Armour, F., \& Valivullah, M. (2005). Enterprise Architecting: Critical Problems. Proceedings of the 38th Annual Hawaii International Conference on System Sciences, $\quad 0(\mathrm{C}), \quad 1-10$. http://doi.org/10.1109/HICSS.2005.241

17.Kamogawa, T., \& Okada, H. (2008). Enterprise architecture and information systems - In Japanese banking industry Proceedings - 2008 International Symposium on Applications and the Internet, SAINT 2008, 433-436. http://doi.org/10.1109/SAINT.2008.66

18. Klischewski, R. (2014). From eGovernment Strategy to Services: Challenges of Inter-organizational IT Governance in Egypt. 8th International Conference on Theory and Practice of Electronic Governance (ICEGOV 2014), 190-199.

http://doi.org/10.1145/2691195.2691257

19.Kumar, R. (2011). RESEARCH METHODOLOGY a step-by-step guide for beginners. SAGE Publication (Vol. 1) http://doi.org/10.1017/CB097811074153 24.004

20.Liimatainen, K., Hoffmann, M., \& Jukka, H. (2007). Overview of Enterprise Architecture work in 15 countries. Finnish Enterprise Architecture Research Project. Retrieved from www.vm.fi/julkaisu

21.Maheshwari, D., Janssen, M., \& van Veenstra, A. F. (2011). A multi-level framework for measuring and benchmarking public service organizations: connecting stages-of-growth models and enterprise architecture. Proceedings of the 5th International Conference on Theory and Practice of Electronic Governance, 73-80. http://doi.org/10.1145/2072069.2072083

22.MAMPU. (2014). Kajian Pembangunan Enterprise Architecture Sektor Awam: Current Assessment Report, (March).

23.MAMPU. (2015). Blueprint for 1 Government Enterprise Architecture (1GovEA). Retrieved from http://www.mampu.gov.my/images/eboo k/1Government Enterprise Architecture (1GovEA) (1).pdf

24.MAMPU. (2016). PELAN STRATEGIK ICT SEKTOR AWAM. Retrieved from http://www.mampu.gov.my/pdf/flipbook/ ispbm2011-2015/files/pelan strategik ict versi bm.pdf

25.Nikpay, F., Ahmad, R., \& Rouhani, B. (2015). Current Issues on Enterprise Architecture Implementation Evaluation. International Journal of Social, Education, Economics and Management Engineering, 9(1), 112-115. http://doi.org/10.1007/978-3-319-059488_23

26.Obi, T., \& Iwasaki, N. (2010). Electronic governance benchmarking - Waseda University e-Gov ranking. ACM International Conference Proceeding Series, $15-20$. http://doi.org/10.1145/1930321.1930325

27.0jo, A., Janowski, T., \& Estevez, E. (2011). Improving Government Enterprise Architecture practice - Maturity factor analysis. Proceedings of the Annual Hawaii International Conference on System Sciences, $\quad$ 4260-4269. http://doi.org/10.1109/HICSS.2012.14

28. Ramakrishnan, S., \& Testani, M. (2011). People, Process , Technology - The Three Elements for a Successful Organizational Transformation. IBM Path Forward to Business Transformation, 1-21. Retrieved 
from

http://www.iienet2.org/Details.aspx?id=2 4456

29. Roeleven, \& Broere. (2009). Why Two Thirds of Enterprise Architecture Projects Fail ARIS Expert Paper.

30.Ross, J. W., Weill, P., \& Robertson, D. (2006). Enterprise Architecture as Strategy: Creating a Foudnation for Business Execution.

31.Rouhani, B. D., Mahrin, M. N. R., Nikpay, F., Ahmad, R. B., \& Nikfard, P. (2015). A systematic literature review on Enterprise Architecture Implementation Methodologies. Information and Software Technology, 62(1), 1-20. http://doi.org/10.1016/j.infsof.2015.01.01 2

32.Saha, P. (2009). A Methodology for Government Transformation with Enterprise Architecture. Advances in Government Enterprise Architecture, 1-29.

33.Salleh, H., Alshawi, M., Mohamed Sabli, N. A., Zolkafli, U. K., \& Judi, S. S. (2011). Measuring Readiness for Successful Information Technology / Information System ( IT / IS ) Project Implementation : A Conceptual Model. African Journal of Business Management, 5(23), 9770-9778. http://doi.org/10.5897/AJBM10.514

34.Schoenherr, M., \& Aier, S. (2005). Sustainable Enterprise ArchitectureCentral (EAI) vs. Decentral (SOA) Approaches to define and establish Flexible Architectures. Proceedings of the VIIth SAM/IFSAM World Congress.

35.Sebastian, M. P., \& Supriya, K. K. (2013). E-governance Readiness: Challenges for India. IIM Kozhikode Society \& Management Review, 2(1), 31-42. http://doi.org/10.1177/22779752134965 11
36.Seppanen, V., Heikkila, J., \& Liimatainen, K. (2009). Key Issues in EAImplementation: Case Study of Two Finnish Government Agencies. 2009 IEEE Conference on Commerce and Enterprise Computing, 114-120. http://doi.org/10.1109/CEC.2009.70

37.Simon, D., Fischbach, K., \& Schoder, D. (2014). Enterprise architecture management and its role in corporate strategic management. Information Systems and E-Business Management, 12(1), 5-42. http://doi.org/10.1007/s10257-013-02134

38.Van Der Raadt, B., Bonnet, M., Schouten, S., \& Van Vliet, H. (2010). The relation between EA effectiveness and stakeholder satisfaction. Journal of Systems and Software, 83(10), 1954-1969. http://doi.org/10.1016/j.jss.2010.05.076

39.van Steenbergen, M., van den Berg, M., \& Brinkkemper, S. (2007). An Instrument for the Development of the Enterprise Architecture Practice. In ICEIS 2007 - 9th International Conference on Enterprise Information Systems, Proceedings (Vol. ISAS, pp. 14-22). Retrieved from http://www.scopus.com/inward/record.ur l?eid=2-s2.0-

45849144290\&partnerID $=40 \& \mathrm{md} 5=177 \mathrm{ec}$ 043e2250f1b1b15545d09f5c840

40.Yin, R. K. (2010). Qualitative Research from Start to Finish. New York: The Guilford Press.

41.Yin, R. K. (2013). Case Study Research Design and Methods (Fifth). SAGE Publications, Inc.

42.Ylimäki, T. (2006). Towards Critical Success Factors for Enterprise Architecture. 